\title{
Aquatic Invasive Species
}

\section{Invasive species are plants or animals that are present in an ecosystem beyond their native range. They may have few natural controls in their new environment and proliferate. They can threaten native species and interfere with human activities. The Western Fisheries Research Center (WFRC) has been conducting research to understand how non-native species invade and affect ecosystems, thus aiding management efforts.}

\section{An Invader From the East Coast}

American shad (Alosa sapidissima) are known to anglers for not giving up easily when hooked. Although they only reach an average of 3 to 5 pounds, they fight like a larger fish. Shad also have fought their way into waters of the West Coast of North America with great success. The native habitat of American shad is the East Coast, although the population has plummeted due to overfishing and development. Conversely, numbers of introduced American shad on the West Coast have increased greatly in the last 50 years. Adult shad migrate up coastal rivers to spawn, and the resulting young shad return to the sea after several months in freshwater. In the Columbia River, over 5 million migrating adults were counted during 2004 at Bonneville Dam

Counts of adult American shad and salmon migrating upriver through Bonneville Dam during 2001

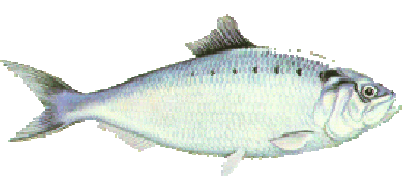

Adult American shad migrating upriver through Bonneville Dam on the Columbia River

country in 7 days. Young shad were in Oregon and Washington State. Furthermore, in the lower river, young shad are one of the most abundant larval and juvenile fishes.

The introduction of American shad to the West occurred in 1871.

Because of shad's value as food fish in the East, the California Fish Commission requested that Seth Green, an enterprising fish culturist, transport shad to the Sacramento River. During the hot month of June, Green used the recently-completed transcontinental railway to move 12,000 small shad across the in four 8-gal milk cans, and Green made stops along the way for fresh water and cooling ice. The transplanted fry survived, and the population grew. Shad migrated out of the Sacramento River into the Pacific Ocean, soon becoming established up and down the coast.

The effects of the high numbers of young and adult American shad on the ecosystem of the West Coast are largely unknown. Shad compete with native and introduced fishes for food and habitat. Fishery biologists are particularly concerned how this may be affecting endangered salmonid populations. However, more research is necessary to understand the role of shad in the western aquatic community.

\section{Eurasian Watermilfoil}

Standing on a bluff overlooking the Columbia River you can see large dark patches in the water. This is an aquatic weed called Eurasian watermilfoil (Myriophyllum spicatum L.) that is native to Europe and Asia 
and has spread dramatically. Scientists are not really sure what effect the Eurasian watermilfoil is having on the Columbia River ecosystem. One thing is for sure, however, the aquatic weed is affecting recreational opportunities for boaters, anglers, swimmers, and windsurfers. Eurasian watermilfoil forms dense mats that can clog boat motors and make swimming difficult.

The WFRC has initiated efforts to help understand the economic and biological effects of Eurasian watermilfoil. The first step is to document the extent of this aquatic weed in the Columbia River. The WFRC has conducted surveys of the weed and the river bottom. We are using this data to develop models that will predict what is promoting or limiting Eurasian watermilfoil in the Columbia River. These models can then be used to help formulate management plans for mitigating this aquatic invader.

\section{Ballast Water}

Although there are several vectors for invasive marine species such as aquaculture, recreational boats, and public aquaria, the most important transportation vector is ballast water carried in commercial ships.

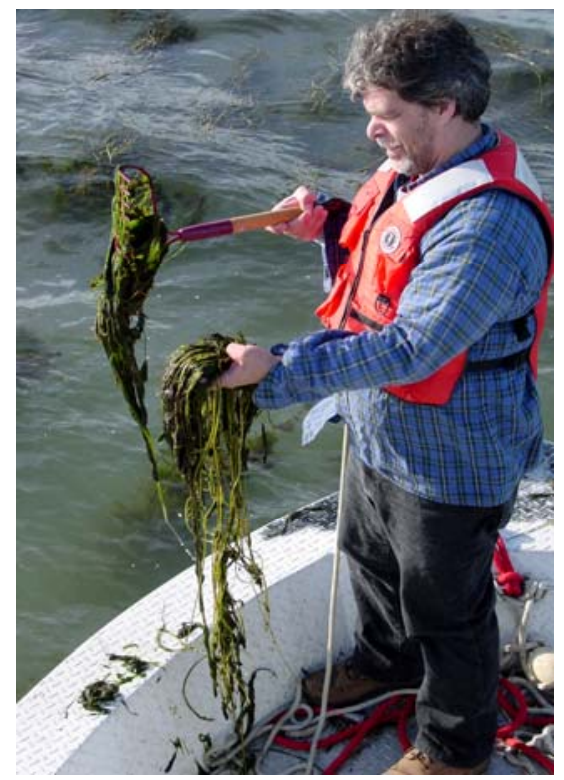

Eurasian watermilfoil in the Columbia River

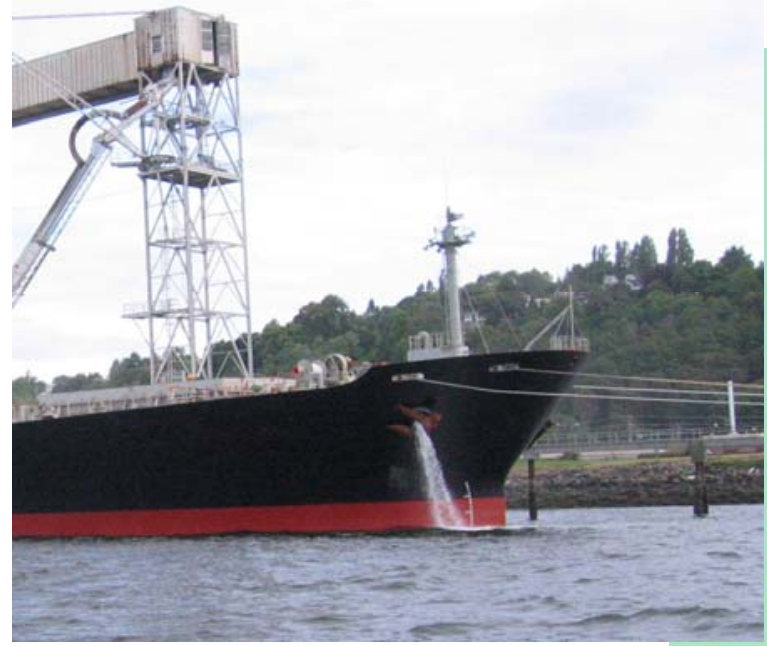

Water is pumped into vast tanks to stabilize a vessel, and later the ballast water is discharged. In this way, animals and plants can be transported thousands of kilometers from their native habitats and deposted in a new environment.

Today there are more than 45,000 commercial cargo-carrying vessels that use ballast water to maintain stability when cargo loads vary.

One ship may contain more than 12 million gallons of ballast water providing a very efficient vector for aquatic microbes, plants, and animals. In fact, it is estimated that 7,000 different species are transported around the world daily in ballast water. Therefore, there is a critical need to develop tools to detect and eradicate invasive species in ballast water prior to their release and establishment in coastal ecosystems. At WFRC, scientists are working to develop DNA markers to detect and monitor invasive species in ballast water and evaluate oceanic exchange. Using stateof-the-art technology, we are developing diagnostic systems to allow as many as 20,000 species to be detected at one time. This technology will allow state and federal agencies to monitor how clean ballast water is before it is dumped in coastal ports.
The Zebra mussel (Dreissena polymorpha) is a rapidly growing invasive species that causes severe fouling problems such as clogging intake pipes, damaging boat hulls, and interfering with the operation of locks and dams.

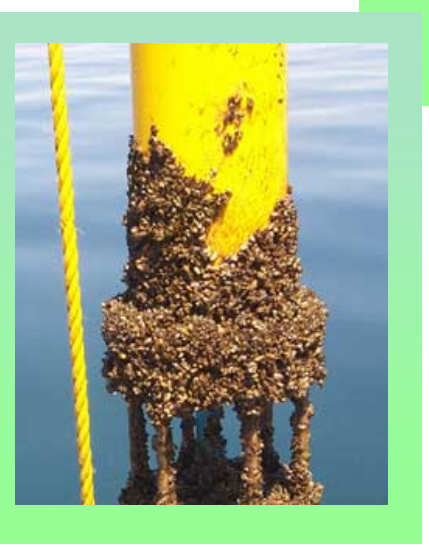

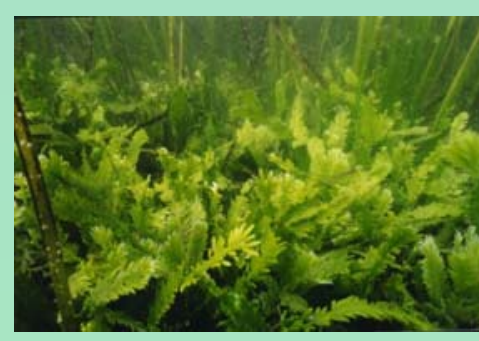

The aquarium strain of Caulerpa taxifolia (C. taxifolia) is an extremely invasive seaweed that has the ability to form a dense carpet on almost any surface.

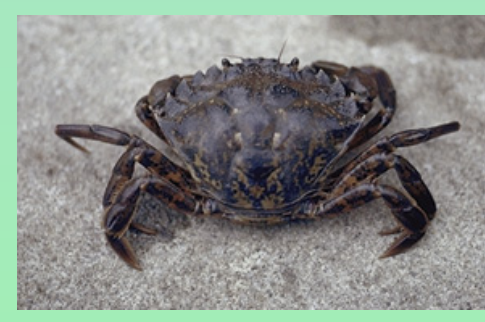

The European Green Crab (Carcinus maenas) is highly adaptable, competing with and displacing native crabs.

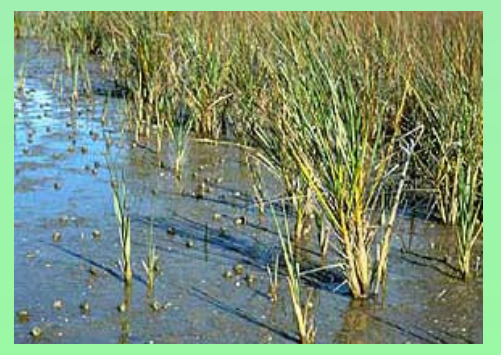

Spartina (Spartina alterniflora, $S$. anglica) is a grass capable of taking over large estuarine areas in the coastal marine zone.

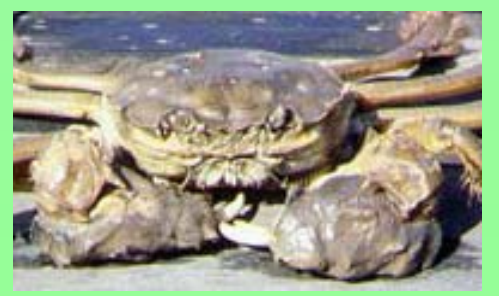
mitten crab (Eriocheir sinensis) can cause shore erosion. To invade a new river system they may leave the water and cross dry land.
The burrowing activities of the Chinese

For additional information, please contact:

Lyman Thorsteinson, Center Director U.S. Geological Survey Western Fisheries Research Center $6505 \mathrm{NE} 65^{\text {th }}$ Street Seattle, WA 98115 